\title{
Selection of ionic liquids for the extraction of aromatic hydrocarbons from aromatic/aliphatic mixtures
}

\author{
G. Wytze Meindersma*, Anita (J.G.) Podt, André B. de Haan \\ University of Twente, Separation Technology Group/Faculty of Science and Technology, P.O. Box 217, 7500 AE Enschede, The Netherlands
}

Received 27 January 2005; received in revised form 6 June 2005; accepted 23 June 2005

\begin{abstract}
The separation of aromatic hydrocarbons (benzene, toluene, ethyl benzene and xylenes) from $\mathrm{C}_{4}$ to $\mathrm{C}_{10}$ aliphatic hydrocarbon mixtures is challenging since these hydrocarbons have boiling points in a close range and several combinations form azeotropes. In this work, we investigated the separation of toluene from heptane by extraction with ionic liquids.

Several ionic liquids are suitable for extraction of toluene from toluene/heptane mixtures. The toluene/heptane selectivities at $40{ }^{\circ} \mathrm{C}$ and $75{ }^{\circ} \mathrm{C}$ with several ionic liquids, [mebupy] $\mathrm{BF}_{4},[$ mebupy $] \mathrm{CH}_{3} \mathrm{SO}_{4},[\mathrm{bmim}] \mathrm{BF}_{4}\left(40{ }^{\circ} \mathrm{C}\right)$ and $[\mathrm{emim}]$ tosylate $\left(75{ }^{\circ} \mathrm{C}\right)$, are a factor of $1.5-2.5$ higher compared to those obtained with sulfolane $\left(S_{\text {tol/hept }}=30.9, D_{\text {tol }}=0.31\right.$ at $\left.40{ }^{\circ} \mathrm{C}\right)$, which is the most industrially used solvent for the extraction of aromatic hydrocarbons from a mixed aromatic/aliphatic hydrocarbon stream. From these five ionic liquids, $[$ mebupy]BF 4 appeared to be the most suitable, because of a combination of a high toluene distribution coefficient $\left(D_{\text {tol }}=0.44\right)$ and a high toluene/heptane selectivity $\left(S_{\text {tol/hept }}=53.6\right)$. Therefore, with [mebupy $] \mathrm{BF}_{4}$ also extraction experiments with other aromatic/aliphatic combinations (benzene/ $n$-hexane, ethylbenzene/ $n$-octane and $m$-xylene/n-octane) were carried out. The aromatic/aliphatic selectivities were all in the same range, from which it can be concluded that the toluene/heptane mixture is a representative model system for the aromatic/aliphatic separation.
\end{abstract}

(C) 2005 Elsevier B.V. All rights reserved.

Keywords: Ionic liquids; Extraction; Toluene; Heptane; Aromatic hydrocarbons; Liquid-liquid equilibrium

\section{Introduction}

The separation of aromatic hydrocarbons (benzene, toluene, ethyl benzene and xylenes) from $\mathrm{C}_{4}$ to $\mathrm{C}_{10}$ aliphatic hydrocarbon mixtures is challenging since these hydrocarbons have boiling points in a close range and several combinations form azeotropes. The conventional processes for the separation of these aromatic and aliphatic hydrocarbon mixtures are liquid extraction, suitable for the range of $20-65$ wt.\% aromatic content, extractive distillation for the range of $65-90$ wt.\% aromatics and azeotropic distillation for high aromatic content, $>90$ wt.\% [53]. Typical solvents used are polar components such as sulfolane [11-13,31,56], $N$-methyl pyrrolidone (NMP) [31], $N$-formyl morpholine (NFM), ethylene glycols $[2,51,56]$, propylene carbonate [1]. This implicates additional distillation steps to separate the extraction solvent from both the extract

* Corresponding author. Tel.: +31 53489 2607; fax: +31 534894821.

E-mail address: g.w.meindersma@utwente.nl (G. Wytze Meindersma). and raffinate phases, and to purify the solvent, with consequently, additional investments and energy consumption. Overviews of the use of extraction and extractive distillation for the separation of aromatic hydrocarbons from aliphatic hydrocarbons can be found elsewhere [18,20,27,41].

According to Weissermel and Arpe [53], no feasible processes are available for the separation of aromatic and aliphatic hydrocarbons in the range below $20 \%$ aromatics in the feed mixture. We are focussing on the separation of aromatic hydrocarbons from the feed stream of naphtha crackers, which may contain up to $25 \%$ aromatics. Preliminary calculations, with confidential information from UOP, showed that extraction with conventional solvents is not an option since additional separation steps are required to purify the raffinate, extract and solvent streams, which would induce high investment and energy costs. The costs of regeneration of sulfolane are high, since the sulfolane, which has a boiling point of 287.3 ${ }^{\circ} \mathrm{C}$, is in the current process taken overhead from the regenerator and returned to the bottom of the aromatics stripper as a vapour [42]. The application of ionic liquids for extraction 
processes is promising because of their non-volatile nature [28]. This facilitates solvent recovery using techniques as simple as flash distillation or stripping.

Aromatic hydrocarbons are reported to have low activity coefficients at infinite dilution in several ionic liquids, while aliphatic hydrocarbons show high activity coefficients in the same ionic liquids $[5,6,14-16,19,22,23,26,28,29,32-$ $34,37,40,43,44]$. In Table 1, aromatic distribution coefficients and aromatic/aliphatic selectivities for toluene/heptane and some other aromatic/aliphatic systems, determined by either extraction $[19,34,37,43]$, solubility $[6,15]$ or by activity coefficients at infinite dilution $[14,19,22,23,29,32,33,40]$ are shown. This suggests that these ionic liquids can be used as extractants for the separation of aromatic hydrocarbons from aliphatic hydrocarbons. Extraction of aromatics from mixed aromatic/aliphatic streams with ionic liquids is expected to require less process steps and less energy consumption than extraction with conventional solvents because ionic liquids have a negligible vapour pressure.

Ionic liquids are organic salts that are liquid at low temperatures $\left(<100{ }^{\circ} \mathrm{C}\right)$ and consist of large organic cations based on methylimidazolium [Rmim], $N$-butylpyridinium $[R-$ $\mathrm{N}$-bupy], quaternary ammonium or phosphonium ions (Fig. 1) and others, and anions such as hexafluorophosphate, tetrafluoroborate, alkylsulfates, alkylsulfonates, chloride, bromide, nitrate, sulfate, aluminium chloride, triflate $\left(\mathrm{CF}_{3} \mathrm{SO}_{3}^{-}\right)$, bis (trifyl)imide $\left(\left(\mathrm{CF}_{3} \mathrm{SO}_{2}\right)_{2} \mathrm{~N}^{-}=\mathrm{Tf}_{2} \mathrm{~N}\right)$, etc. [10]. The $\mathrm{R}$ group of the cation is variable (e.g. methyl, ethyl, butyl, etc.). The<smiles></smiles><smiles>[R]c1cc[n+](CCCC)cc1</smiles><smiles>[R4][N+]([R3])([R3])[R]</smiles><smiles>[R][PH]([R])([R])C</smiles>

Fig. 1. Structure of 1-R-3-methylimidazolium, 4- $R-N$-butylpyridinium, quaternary ammonium and quaternary phosphonium cations.

variability of the anion and $\mathrm{R}$ groups in the imidazolium, pyridinium, ammonium or phosphonium cations may be used to adjust the properties of the ionic liquids. Ionic liquids have a wide liquid range $\left(\sim 300{ }^{\circ} \mathrm{C}\right)$, which allows a better kinetic control on reactions. They are non-flammable, have a high thermal stability and a high ionic conductivity. These properties permit their use in many fields. They are used as reaction media to substitute VOCs, as homogeneous catalysts and as extractive media in liquid-liquid extraction processes [16,28]. However, the use of ionic liquids also has some disadvantages: the physical properties are not always known, their viscosity is usually higher than common solvents and their toxicity is unknown. In order for a successful application of ionic liquids in industrial processes, these aspects must be taken into consideration.

The use of ionic liquids in separations is presently mostly in the extraction of metal ions with $[\mathrm{bmim}] \mathrm{PF}_{6},[\mathrm{hmim}] \mathrm{PF}_{6}$ and other $\mathrm{PF}_{6}^{-}$-based ILs $[47,48,50,52]$, alcohols using [bmim] $\mathrm{PF}_{6}$, [omim] $\mathrm{PF}_{6}$ and $\left[\mathrm{Rmim} \mathrm{PF}_{6}[17,24,55]\right.$, separation of alcohols

Table 1

Overview of measured distribution coefficients and selectivities for aromatic/aliphatic separations

\begin{tabular}{|c|c|c|c|c|c|c|c|}
\hline Solvent & Separation & $T\left({ }^{\circ} \mathrm{C}\right)$ & Mole \% arom. & $D_{\text {arom }}$ & $S_{\text {arom/alk }}$ & Remarks & Ref. \\
\hline Sulfolane & Toluene/heptane & 40 & 5.9 & 0.31 & 30.9 & This work & \\
\hline$[\mathrm{emim}] \mathrm{I}_{3}$ & Toluene/heptane & 45 & 7.5 & 0.84 & 48.6 & Very corrosive & {$[43]$} \\
\hline$[\mathrm{bmim}] \mathrm{I}_{3}$ & Toluene/heptane & 35 & 17.0 & 2.3 & 30.1 & Very corrosive & {$[43]$} \\
\hline \multirow[t]{5}{*}{ [omim] $\mathrm{Cl}$} & Benzene/heptane & 25 & 26.6 & 0.58 & $6.1^{\mathrm{a}}$ & Extraction & {$[34]$} \\
\hline & Benzene/heptane & 25 & - & 0.50 & 10.7 & Activity coefficients & {$[14]$} \\
\hline & Benzene/heptane & 40 & - & 0.63 & 11.3 & Activity coefficients & {$[40]$} \\
\hline & Toluene/heptane & 35 & - & 0.38 & 8.0 & Activity coefficients & {$[14]$} \\
\hline & Toluene/heptane & 40 & - & 0.43 & 7.7 & Activity coefficients & {$[40]$} \\
\hline$[\mathrm{mmim}] \mathrm{Tf}_{2} \mathrm{~N}$ & Toluene/heptane & 40 & - & 0.49 & 29.8 & Activity coefficients & {$[32]$} \\
\hline \multirow[t]{5}{*}[\mathrm{emim}]{$\mathrm{Tf}_{2} \mathrm{~N}$} & Benzene/cyclohexane & 24.5 & 27.8 & n.a. & 17.7 & Extraction & {$[19]$} \\
\hline & Benzene/cyclohexane & 30 & - & 0.84 & 13.2 & Activity coefficients & [19] \\
\hline & Toluene/heptane & 40 & - & 0.55 & 22.2 & Activity coefficients & {$[32]$} \\
\hline & Toluene/heptane & 40 & - & 0.58 & 22.1 & Activity coefficients & {$[23]$} \\
\hline & Toluene/heptane & 40 & - & 0.56 & 16.5 & Activity coefficients & {$[40]$} \\
\hline$[\mathrm{bmim}] \mathrm{Tf}_{2} \mathrm{~N}$ & Toluene/heptane & 40 & - & 0.81 & 16.7 & Activity coefficients & {$[32]$} \\
\hline$[\mathrm{emmim}] \mathrm{Tf}_{2} \mathrm{~N}$ & Toluene/heptane & 40 & - & 0.61 & 22.7 & Activity coefficients & {$[23]$} \\
\hline \multirow[t]{4}{*}[\mathrm{bmim}]{$\mathrm{PF}_{6}$} & Benzene/cyclohexane & 22 & - & 0.66 & 3.1 & Solubility & {$[6]$} \\
\hline & Toluene/heptane & 68 & - & 0.43 & 9.7 & Solubility & {$[15]$} \\
\hline & Toluene/heptane & 40 & - & 0.34 & 21.3 & Activity coefficients & {$[40]$} \\
\hline & Toluene/heptane & 60 & - & 0.30 & 18.3 & Activity coefficients & {$[40]$} \\
\hline \multirow[t]{2}{*}[\mathrm{hmim}]{$\mathrm{PF}_{6}$} & Benzene/heptane & 25 & 4.1 & 0.70 & $8.2^{\mathrm{a}}$ & Extraction & {$[37]$} \\
\hline & Benzene/heptane & 25 & - & 0.97 & 29.7 & Activity coefficients & {$[33]$} \\
\hline$[\mathrm{hmim}] \mathrm{BF}_{4}$ & Benzene/heptane & 25 & 12.8 & 0.81 & 8.4 & Extraction & {$[37]$} \\
\hline [mebupy]BF 4 & Toluene/heptane & 40 & - & 0.38 & 32.8 & Activity coefficients & {$[22]$} \\
\hline$[\mathrm{mmim}]\left(\mathrm{CH}_{3}\right)_{2} \mathrm{PO}_{4}$ & Toluene/octane & 40 & - & 0.14 & 48.0 & Activity coefficients & {$[29]$} \\
\hline$[\mathrm{mmim}] \mathrm{CH}_{3} \mathrm{SO}_{4}$ & Toluene/heptane & 40 & - & 0.06 & 16.4 & Activity coefficients & {$[29]$} \\
\hline$[\mathrm{emim}] \mathrm{C}_{2} \mathrm{H}_{5} \mathrm{SO}_{4}$ & Toluene/heptane & 40 & - & 0.19 & 43.0 & Activity coefficients & {$[32]$} \\
\hline
\end{tabular}

Data from literature.

a Selectivity calculated from the data given. 
and alkanes or alkenes with [omim] Cl, [hmim] $\mathrm{BF}_{4}$ or [hmim] $\mathrm{PF}_{6}[35,36]$, desulphurisation of oils with [emim] $\mathrm{AlCl}_{4}$, $[\mathrm{bmim}] \mathrm{AlCl}_{4},[\mathrm{bmim}] \mathrm{BF}_{4},[\mathrm{bmim}] \mathrm{PF}_{6}$, trimethylamine hydrochloride $/ \mathrm{AlCl}_{3}$, [emim] ethylsulfate and [bmim] octylsulfate [7,57-59], ethers from ethanol with [omim] $\mathrm{Cl}$ and [bmim] trifluoromethanesulfonate $[3,4]$. It is also possible to separate compounds from each other by selective transport by using supported liquid membranes based on ionic liquids, such as [bmim $] \mathrm{PF}_{6}[8,9,39]$. Environmental pollutants, such as aromatic and polycyclic aromatic hydrocarbons, can be extracted from aqueous solutions with ionic liquids $[\mathrm{bmim}] \mathrm{PF}_{6}$ and [omim] $\mathrm{PF}_{6}$ [38]. There are only a few publications concerning extraction of aromatic hydrocarbons from mixtures of aromatic and aliphatic hydrocarbons, notably with $[\mathrm{emim}] \mathrm{I}_{3},[\mathrm{bmim}] \mathrm{I}_{3}$, [emim $]\left(\mathrm{CF}_{3} \mathrm{SO}_{2}\right)_{2} \mathrm{~N}$, [omim] Cl, [hmim] $\mathrm{BF}_{4}$ and $[\mathrm{hmim}] \mathrm{PF}_{6}$ $[19,35,37,43]$.

It is remarkable that most of the ionic liquids used for extraction of the compounds mentioned are $\mathrm{PF}_{6}^{-}$-containing imidazolium-based ionic liquids. The reason is that these ionic liquids are very versatile and easy to prepare, although HF formation is likely, as is reported by Swatloski et al. [46].

The requirements of a suitable ionic liquid for the separation of aromatic and aliphatic hydrocarbons are:

- High solubility of aromatic hydrocarbons in the IL

- No or low solubility of aliphatic hydrocarbons in the IL

- High separation factor and a high distribution coefficient

- Simple recovery of the IL from both the extract and the raffinate phase

- Fast mass transport from the feed phase to the IL phase.

A higher selectivity means a purer product and less extraction of aliphatics and a higher distribution coefficient requires a lower solvent to feed ratio.

\section{Selection of suitable ionic liquids}

Brennecke and Maginn [10] reported that until that date hardly any chemical engineer was involved in the design and development of ionic liquids for practical applications. Considering the low number of relevant publications on extractions and other separations, this is still true today. Besides the publications about extraction of aromatic and aliphatic hydrocarbons, other publications concerning this separation are patents, mainly dealing with extraction of dibenzothiophene from dodecane with trimethylamine hydrochloride $/ \mathrm{Al}_{2} \mathrm{Cl}_{7}$ or trimethylamine hydrochloride $/ \mathrm{AlCl}_{3}$ and absorption of single components in these ionic liquids [44] or extractive distillation of close boiling compounds and azeotropic mixtures with for instance $[\mathrm{omim}] \mathrm{BF}_{4}$, $[\mathrm{emim}] \mathrm{BF}_{4}$, [emim] $\mathrm{PF}_{6}$, etc. [5]. Although the separation of aromatic and aliphatic hydrocarbons is claimed in the patent by Arlt et al. [5], no examples of this separation are given.

The extraction of toluene from mixtures of toluene and heptane is used as a model for the aromatic/aliphatic separation. The mixture of $10(\mathrm{v} / \mathrm{v}) \%$ toluene in heptane is taken as a reference for the selection of ionic liquids for the aromatic/aliphatic separation at two temperatures (40 and 75 $\left.{ }^{\circ} \mathrm{C}\right)$. Based on initial screening results, three ionic liquids are chosen for more detailed equilibrium tests. Extraction experiments with other aromatic/aliphatic hydrocarbons will be performed with the most suitable ionic liquid from these selection tests. The solvent sulfolane is used as a benchmark for this separation $\left(S_{\text {tol/hept }}=30.9, D_{\text {tol }}=0.31\right.$ at $\left.40{ }^{\circ} \mathrm{C}\right)$, because it is one of the most common solvents for extraction of aromatic hydrocarbons from mixtures of aromatic and aliphatic hydrocarbons used in industry. Therefore, suitable ionic liquids for this separation must show $S_{\text {tol/hep }} \geq 30$ and/or $D_{\text {toluene }} \geq 0.3$ at $40{ }^{\circ} \mathrm{C}$. From Table 1, only the following ionic liquids have a sufficiently high aromatic/aliphatic selectivity $\left(S_{\text {tol/hep }}>30\right)$ : [emim] $\mathrm{I}_{3}$, [bmim] $\mathrm{I}_{3},[\mathrm{emim}] \mathrm{C}_{2} \mathrm{H}_{5} \mathrm{SO}_{4},[\mathrm{mmim}]\left(\mathrm{CH}_{3}\right)_{2} \mathrm{PO}_{4}$ and [mebupy] $\mathrm{BF}_{4}$.

Since both the toluene/heptane selectivities and the toluene distribution coefficients with $[\mathrm{emim}] \mathrm{I}_{3}$ and $[\mathrm{bmim}] \mathrm{I}_{3}$ were higher than those with sulfolane, we planned to repeat and expand these results, but we soon stopped experimenting with these ionic liquids, because they appeared extremely corrosive. The other suitable ionic liquids with a high toluene/ heptane selectivity with a reasonable toluene distribution coefficient are $[\mathrm{emim}] \mathrm{C}_{2} \mathrm{H}_{5} \mathrm{SO}_{4},[\mathrm{mmim}]\left(\mathrm{CH}_{3}\right)_{2} \mathrm{PO}_{4}$ and [mebupy] $\mathrm{BF}_{4}$. Since several ionic liquids from Table 1 were either not suitable due to corrosion ([emim $]_{3}$ and $[\mathrm{bmim}]_{3}$ ) or showed a too low aromatic/aliphatic selectivity, other ionic liquids must be selected for the separation of toluene from toluene/heptane mixtures. However, information in literature on specific properties of ionic liquids, such as miscibility with aromatic and/or aliphatic hydrocarbons, activity coefficients at infinite dilution or selectivities, is scarce and sometimes misleading, such as the values of the benzene/heptane selectivity with $[\mathrm{hmim}] \mathrm{PF}_{6}$, obtained with extraction (8.2) and calculated from the activity coefficients at infinite dilution (29.7), as can be seen in Table 1. Therefore, screening of suitable ionic liquids cannot be entirely based on literature data. Hence, the selection of ionic liquids suitable for the separation of aromatic and aliphatic hydrocarbons is partly speculative. Brennecke and Maginn [10] reported that halide containing ILs are certainly corrosive and Swatloski et al. [46] reported that $\mathrm{HF}$ formation is possible when using [bmim] $\mathrm{PF}_{6}$. Therefore, ionic liquids with $\mathrm{PF}_{6}^{-}$as anion were excluded.

The following imidazolium containing ionic liquids were selected: [Hmim] hydrogensulfate $(\mathrm{H}=$ hydrogen$),[\mathrm{mmim}]$ methylsulfate (if Kato and Gmehling [29] already would have published their results when we made this selection, we would probably not have chosen this IL, but our measured toluene/heptane selectivity, 69.0, is quite different from the selectivity calculated by activity coefficients at infinite dilution, 16.4.), [mmim] dimethylphosphate, [emim] hydrogensulfate, [emim] methylsulfonate, [emim] ethylsulfate, [emim] diethylphosphate, [emim] tosylate, [emim] tetrafluoroborate, $[\mathrm{bmim}]$ tetrafluoroborate, $[\mathrm{bmim}]$ methylsulfate and [omim] tetrafluoroborate. (Letcher and Reddy [37] had not yet published their results at the time when the selection was 
made. Otherwise, we would not have chosen this IL.) The length of the alkyl chain on the imidazolium cation was varied from none (hydrogen) to octyl. A shorter R group is favourable for a high aromatic/aliphatic selectivity, but results in a decrease in the distribution coefficient [32]. This observation of a higher selectivity with shorter R-groups is in accordance with the findings of Hanke et al. [21]. The existence of $\pi$-electrons in orbitals above and below an aromatic ring results in a much stronger electrostatic field around an aromatic molecule compared to a saturated aliphatic molecule. Alkyl substitution on the aromatic ring may effectively disturb the molecular interaction in preferred orientation.

Next to the imidazolium containing ionic liquids, butylpyridinium ILs were tested, because we expect a higher interaction between the aromatic ring of the hydrocarbons and the pyridinium ring of the IL. The pyridinium containing ionic liquids tested were [bupy] methylsulfate, [mebupy] methylsulfate and [mebupy] tetrafluoroborate [22]. Also, an isoquinolinium IL, ethylisoquinolinium ethylsulfate, was chosen, because of the conjugated aromatic rings of this compound, which could result in a high aromatic selectivity [49]. Beside imidazolium, pyridinium and isoquinolinium containing ionic liquids, one quaternary ammonium IL, methyl-tributylammonium methylsulfate, and a quaternary phosphonium IL, tetrabutylphosphonium bis[oxalato(2-)]borate, were chosen.

\section{Experimental section}

\subsection{Chemicals}

The ionic liquids 1,3-dimethylimidazolium methylsulfate ([mmim $] \mathrm{CH}_{3} \mathrm{SO}_{4}$ ) (98\%), 1,3-dimethylimidazolium dimethylphoshate $\left([\mathrm{mmim}]\left(\mathrm{CH}_{3}\right)_{2} \mathrm{PO}_{4}\right)(>98 \%)$, 1-butyl-3-methylimidazolium methylsulfate $\left([\mathrm{bmim}] \mathrm{CH}_{3} \mathrm{SO}_{4}\right)(98 \%)$ and 1-ethyl-3methylimidazolium tosylate $\left([\mathrm{emim}] \mathrm{C}_{7} \mathrm{H}_{7} \mathrm{SO}_{3}\right)$ (98\%) were purchased from Solvent Innovation. Sulfolane ( $>98 \%)$, diethylsulfate $(>99 \%)$ and the ionic liquids 1-ethyl-3-methylimidazolium tetrafluoroborate $\left([\mathrm{emim}] \mathrm{BF}_{4}\right)(>97 \%), 1-$ octyl-3-methylimidazolium tetrafluoroborate $\left([\mathrm{omim}] \mathrm{BF}_{4}\right)$ $(>97 \%)$ and 4-methyl- $N$-butylpyridinium tetrafluoroborate ([mebupy] $\left.\mathrm{BF}_{4}\right)(>97 \%)$ were purchased from Fluka. Toluene (p.a.), $n$-heptane (p.a.), 1-butanol (p.a., >99\%), 1-methylimidazole (for synthesis, $>99 \%$ ) and the ionic liquids 1-butyl3-methylimidazolium tetrafluoroborate $\left(\left[\mathrm{bmim}^{-} \mathrm{BF}_{4}\right)\right.$, $\mathrm{N}$-butylpyridinium methylsulfate ([bupy] $\mathrm{CH}_{3} \mathrm{SO}_{4}$ ), 3methyl- $N$-butylpyridinium methylsulfate [mebupy] $\mathrm{CH}_{3} \mathrm{SO}_{4}$ ) and tetrabutylphosphonium bis[oxalato(2-)]borate $\left(\left[\left(\mathrm{C}_{4} \mathrm{H}_{9}\right)_{4}\right.\right.$ $\mathrm{P}_{4} \mathrm{C}_{4} \mathrm{BO}_{8}$ ) (purity: for synthesis) were purchased from Merck. The ionic liquids 1-methylimidazolium hydrogensulfate $\left([\mathrm{Hmim}] \mathrm{HSO}_{4}\right)$, 1-ethyl-3-methylimidazolium hydrogensulfate $\left([\mathrm{emim}] \mathrm{HSO}_{4}\right)$, 1-ethyl-3-methyl-imidazolium methylsulfonate ([emim $] \mathrm{CH}_{3} \mathrm{SO}_{3}$ ), 1-ethyl-3-methylimidazolium diethylphosphate $\left([\mathrm{emim}]\left(\mathrm{C}_{2} \mathrm{H}_{5}\right)_{2} \mathrm{PO}_{4}\right)$ and methyl-tributylammonium methylsulfate $\left(\left[\mathrm{CH}_{3}-\mathrm{N}-\left(\mathrm{C}_{4} \mathrm{H}_{9}\right)_{3}\right] \mathrm{CH}_{3} \mathrm{SO}_{4}\right.$ or MTBS) were obtained from BASF. Acetone- $\mathrm{d}_{6},(99.5$ at. $\%$ D) was purchased from Aldrich.

\subsection{Preparation of [emim] ethylsulfate and ethyl-isoquinoli- nium ethylsulfate}

The ionic liquid 1-ethyl-3-methylimidazolium ethylsulfate was prepared from 1-methylimidazole (Merck-Schuchardt, $>99 \%$ ) and diethylsulfate (Fluka, $>99 \%$ ) according to the procedure described by Holbrey et al. [25]. Diethyl sulfate $(116 \mathrm{~mL})$ was added drop-wise to a mixture of 1-methylimidazole $(70 \mathrm{~mL})$ in toluene $(400 \mathrm{~mL})$, cooled in an ice-bath under argon. After addition of the diethylsulfate, the reaction mixture was stirred at room temperature for $5 \mathrm{~h}$. Formation of two phases occurred: the toluene solution and a denser ionic liquid phase. The upper, organic phase was decanted and the lower, ionic liquid phase, was three times washed with toluene (total amount of toluene: $200 \mathrm{~mL}$ ), dried at $75{ }^{\circ} \mathrm{C}$ under reduced pressure $(0$ bar) in a rotary evaporator and finally in a vacuum exsiccator to remove any residual organic solvents.

Samples of this ionic liquid were dissolved in acetone- $\mathrm{d}_{6}$ and analysed by ${ }^{1} \mathrm{H}$ NMR (Varian $300 \mathrm{MHz}$ ).

The ionic liquid 1-ethyl-isoquinolinium ethylsulfate $\left(\left[\mathrm{C}_{9} \mathrm{H}_{7}\right.\right.$ $\left.\mathrm{N}-\mathrm{C}_{2} \mathrm{H}_{5}\right] \mathrm{C}_{2} \mathrm{H}_{5} \mathrm{SO}_{4}$ ) was prepared from isoquinoline (Fluka, $>97 \%$ ) and diethylsulfate according to the procedure described by Willems and Nys [54], but with toluene as the solvent instead of benzene.

\subsection{Experimental procedure}

Before each experiment, the ionic liquids were dried at 75 ${ }^{\circ} \mathrm{C}$ under reduced pressure in a rotary evaporator (Büchi Rotavapor R-200), because all ionic liquids are very hygroscopic and the presence of water can change their properties. Liquid-liquid extraction experiments were carried out in jacketed vessels with a volume of approximately 70 $\mathrm{mL}$. The top of the vessel was closed using a PVC cover, through which a stirrer shaft passed. Two stainless steel propellers were used with an electronic stirrer (Heidolph RZR 2051 control). The vessels were jacketed to circulate water from a water bath (Julabo F32-MW) in order to maintain the temperature inside the vessels at either 40 or 75 ${ }^{\circ} \mathrm{C} \pm 0.1{ }^{\circ} \mathrm{C}$.

For each experiment, $20 \mathrm{~mL}$ of the ionic liquid and $10 \mathrm{~mL}$ of a toluene $/ n$-heptane mixture were placed into the vessel. The temperature and the ratio of toluene in $n$-heptane were varied. We established that equilibrium was reached within $5 \mathrm{~min}$. This was done for one IL by taking samples after $5,10,15,30,65$ and $120 \mathrm{~min}$ and analysing them. In order to avoid this procedure for the other ternary mixtures, the extraction experiment was continued for $20 \mathrm{~min}$. After stirring, the two phases were allowed to settle for about $1 \mathrm{~h}$.

\subsection{Analysis}

Samples (approximately $0.5 \mathrm{~mL}$ ) were taken from both phases. 1-Butanol $(0.5 \mathrm{~mL})$ was added to each sample to avoid phase splitting and to maintain a homogeneous mixture, and $n$ hexane was added to samples as an internal standard for the GC 
analysis, $0.2 \mathrm{~mL}$ to the raffinate phase and $0.1 \mathrm{~mL}$ to the extract phase samples. For the analysis of $n$-hexane from the experiments with mixtures of benzene $+n$-hexane, acetone was used as solvent instead of 1-butanol and $n$-pentane was used as the internal standard.

The concentrations of toluene and $n$-heptane in the samples were analysed by a Varian CP-3800 gas chromatograph with an Alltech Econo-Cap EC-Wax column (30 $\mathrm{m} \times 0.32 \mathrm{~mm} \times 0.25 \mu \mathrm{m})$ and with a Varian 8200 AutoSampler. Because the ionic liquid has no vapour pressure, it cannot be analysed by GC. The IL was collected in a precolumn in order not to disrupt the analysis. The GC program parameters for the analyses are:

\begin{tabular}{ll}
\hline Column oven & $35{ }^{\circ} \mathrm{C}(1 \mathrm{~min}) \rightarrow 115^{\circ} \mathrm{C}\left(40{ }^{\circ} \mathrm{C} / \mathrm{min}\right)$; benzene/hexane \\
& $(1.2 \mathrm{~min}) \rightarrow 70{ }^{\circ} \mathrm{C}$ \\
Carrier gas & hydrogen; column flow $3 \mathrm{~mL} / \mathrm{min}$ \\
Injector & $250{ }^{\circ} \mathrm{C} ;$ split ratio $1: 100$ raffinate and $1: 25$ extract phase \\
Detector & FID; $250{ }^{\circ} \mathrm{C}$ \\
\hline
\end{tabular}

In a ternary mixture, one has to analyse only two components and the third one, the IL, can then be determined by subtracting the sum of the measured molar fractions of the aromatic and the aliphatic hydrocarbons from a value of 1 .

Measurements were carried out in duplicate in order to increase the accuracy in the measurements. Each sample was injected in triple. The deviation in the calibration curves with a maximum of $1 \%$ and a possible contamination of the gas chromatograph can cause a variance in the mole fractions (estimated on $1 \%$ ). The averages of the two measurements were used in our results. As a consequence, the errors in the determination of the distribution coefficients and the selectivities are normally around $2 \%$ and $5 \%$, respectively. However, when the heptane concentrations in the extract phase are very small with an error of $0.001 \mathrm{~mol}$ fraction, especially with $[\mathrm{mmim}] \mathrm{CH}_{3} \mathrm{SO}_{4}$, the error in the selectivity can be as high as $10 \%$, as shown in Fig. 6.

\section{Results and discussion}

\subsection{Screening experiments with toluene/heptane mixtures at 40 and $75^{\circ} \mathrm{C}$}

Liquid-liquid equilibrium data were collected for mixtures of 5,10 and $15 \mathrm{v} / \mathrm{v} \%$ toluene in heptane at 40 and $75^{\circ} \mathrm{C}$ with the selected ionic liquids. The distribution coefficient, $D_{\mathrm{i}}$, is directly calculated from the ratio of the mole fractions in the extract and raffinate phases at equilibrium. The distribution coefficients of toluene and heptane are defined by the ratio of the mole fractions of the solute in the extract (IL) phase and in the raffinate (organic) phase, according to:

$D_{\mathrm{tol}}=C_{\mathrm{tol}}^{\mathrm{IL}} / C_{\text {tol }}^{\mathrm{org}}$ and $D_{\text {hept }}=C_{\mathrm{hept}}^{\mathrm{IL}} / C_{\text {hept }}^{\mathrm{org}}$

The selectivity, $S_{\text {tol/hept }}$, of toluene/heptane is defined as the ratio of the distribution coefficients of toluene and heptane:

$S_{\text {tol } / \text { hept }}=D_{\text {tol }} / D_{\text {hept }}=\left(C_{\text {tol }}^{\mathrm{IL}} / C_{\text {tol }}^{\text {org }}\right) /\left(C_{\text {hept }}^{\mathrm{IL}} / C_{\text {hept }}^{\text {org }}\right)$.

The results of the experiments with $10(\mathrm{v} / \mathrm{v}) \%$ toluene in the feed at $40{ }^{\circ} \mathrm{C}$ are shown in Fig. 2, and the results at $75{ }^{\circ} \mathrm{C}$ in Fig. 3. In these figures, the toluene/heptane selectivity is shown as function of the distribution coefficient of toluene. Some of the ionic liquids used are not liquid at $40{ }^{\circ} \mathrm{C}$ and were tested at $75{ }^{\circ} \mathrm{C}$ only: [emim] tosylate (m.p. $\sim 48{ }^{\circ} \mathrm{C}$ ), [1-ethylisoquinolinium] ethylsulfate (m.p. $\sim 88{ }^{\circ} \mathrm{C}$ ), [tetrabutylphosphonium] bis[oxalato(2-)]borate] (m.p. $43^{\circ} \mathrm{C}$ ), and [methyltributylammonium] methylsulfate (m.p. $62{ }^{\circ} \mathrm{C}$ ).

At $75^{\circ} \mathrm{C}$, the distribution coefficients of toluene with most of the ionic liquids tested remain at about the same level or are slightly lower compared to those at $40{ }^{\circ} \mathrm{C}$. The interaction of the ionic liquid with the aromatic toluene is mainly $\pi$-ionic nature, which is not very dependent on temperature [21]. However, the toluene distribution coefficients with $[\mathrm{emim}] \mathrm{CH}_{3} \mathrm{SO}_{3}$ decrease dramatically with temperature: from 0.44 to 0.12 . This is seen at all toluene concentrations tested. Surprisingly, the selectivity

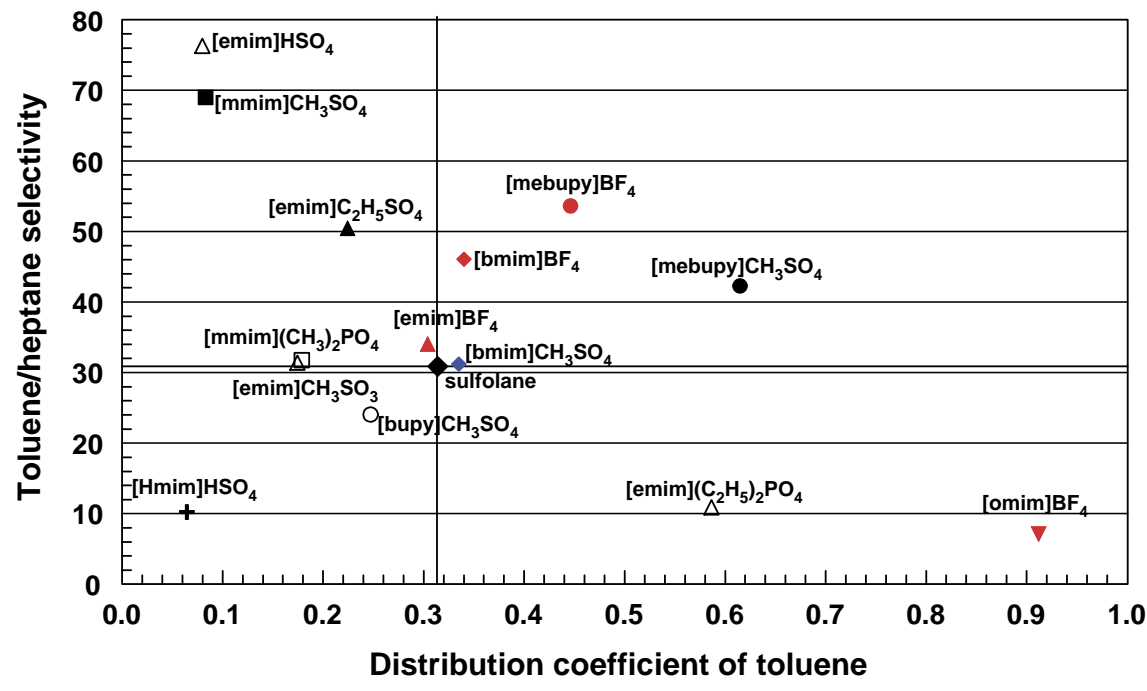

Fig. 2. Toluene/heptane separation with ionic liquids, $10(\mathrm{v} / \mathrm{v}) \%$ toluene, $T=40{ }^{\circ} \mathrm{C}$. 


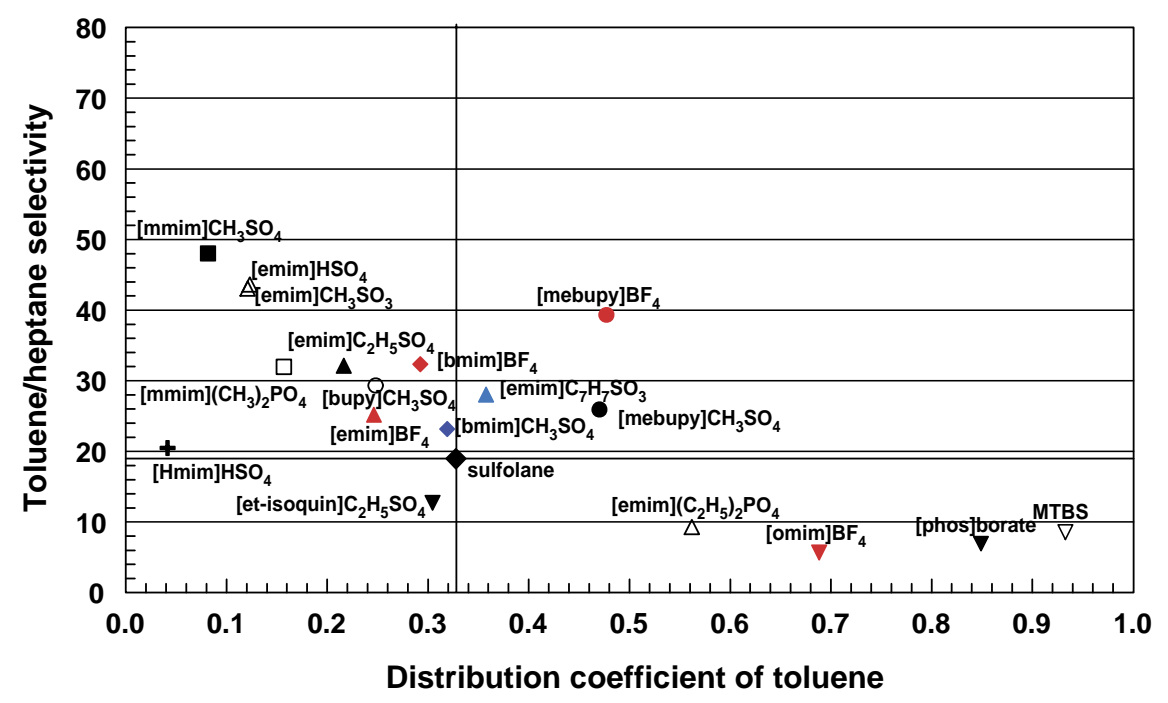

Fig. 3. Toluene/heptane separation with ionic liquids, $10(\mathrm{v} / \mathrm{v}) \%$ toluene, $T=75^{\circ} \mathrm{C}$.

with [emim] $\mathrm{CH}_{3} \mathrm{SO}_{3}$ increases with temperature, from 25.6 to 43.1. Hanke et al. [21] reported differences in interaction of benzene and the ionic liquids $[\mathrm{mmim}] \mathrm{Cl}$ and $\left[\mathrm{mmim}^{2} \mathrm{PF}_{6}\right.$, indicating that the nature of the anion does have an effect on the interaction. The interaction of the methylsulfonate groups with toluene is apparently less at higher temperatures. For [mebupy] $\mathrm{CH}_{3} \mathrm{SO}_{4}$ and also for the three $\mathrm{BF}_{4}^{-}$containing imidazolium ionic liquids, the toluene distribution coefficients decrease about $15-25 \%$ with increasing temperature. As the distribution coefficients of heptane increase with temperature in most cases, the toluene/heptane selectivities with the ionic liquids tested will decrease with temperature.

Comparing the results at $40{ }^{\circ} \mathrm{C}$ with the different toluene contents of the mixture, it is apparent that the ionic liquids [mebupy $] \mathrm{BF}_{4},[\mathrm{bmim}] \mathrm{BF}_{4}$ and [mebupy $] \mathrm{CH}_{3} \mathrm{SO}_{4}$ show both a higher toluene distribution coefficient and a higher toluene/ heptane selectivity than sulfolane. Also at $75{ }^{\circ} \mathrm{C}$, the ionic liquids [mebupy] $\mathrm{BF}_{4},\left[\right.$ mebupy] $\mathrm{CH}_{3} \mathrm{SO}_{4}$ as well as [emim] tosylate show both a higher toluene distribution coefficient and a higher toluene/heptane selectivity than sulfolane.

\subsection{Effect of alkyl chain length}

Comparison of the experiments with ionic liquids [emim] ethylsulfate and [mmim] methylsulfate and with [emim] diethylphosphate and $[\mathrm{mmim}]$ dimethylphosphate at $10(\mathrm{v} /$ v) $\%$ toluene (Figs. 2 and 3) lead to the conclusion that a shorter alkyl chain on the imidazolium ion is favourable for higher aromatic/aliphatic selectivities, but results to lower distribution coefficients, as expected from the data of Krummen et al. [32]. The same observation holds for [emim] $\mathrm{BF}_{4}$ and $[\mathrm{omim}] \mathrm{BF}_{4}$. However, if the results of $[\mathrm{emim}] \mathrm{BF}_{4}$ and $[\mathrm{bmim}] \mathrm{BF}_{4}$ are compared, the unexpected conclusion is that a butyl chain on the imidazolium ion with $\mathrm{BF}_{4}^{-}$as anion gives both a higher distribution coefficient of toluene and a higher toluene/heptane selectivity.

Apparently, the absence of an alkyl chain on the imidazolium group leads to a lower selectivity as can be seen by comparing the results of $[\mathrm{Hmim}] \mathrm{HSO}_{4}$ and $[\mathrm{emim}] \mathrm{HSO}_{4}$ at $10(\mathrm{v} / \mathrm{v}) \%$ toluene (Figs. 2 and 3) $\left(40^{\circ} \mathrm{C}: S_{\text {tol/hept }}=10.2\right.$ and $S_{\text {tol/hept }}=76.3$; $75{ }^{\circ} \mathrm{C}: S_{\text {tol } / \text { hept }}=20.5$ and $S_{\text {tol/hept }}=43.6$, respectively). The same observation can be made for the butylpyridinium ion at $40{ }^{\circ} \mathrm{C}$, as the methyl group has a favourable effect on both the distribution coefficient of toluene and the toluene/heptane selectivity, as can be seen by comparing [bupy] methylsulfate $\left(D_{\text {tol }}=0.25, S_{\text {tol } / \text { hept }}=24.0\right)$ and [mebupy] methylsulfate $\left(D_{\text {tol }}=0.61, S_{\text {tol/hept }}=42.3\right)$. However, at $75{ }^{\circ} \mathrm{C}$, the toluene distribution coefficient with [mebupy] $\mathrm{CH}_{3} \mathrm{SO}_{4}$ is higher than with [bupy] $\mathrm{CH}_{3} \mathrm{SO}_{4}$ (0.47 and 0.25), but the toluene/heptane selectivity is slightly lower (25.9 and 29.3).

A shorter alkyl group on the imidazolium cation of the ionic liquids generally results in a more aromatic character of the ionic liquid and hence to a higher toluene distribution coefficient and to a higher toluene/heptane selectivity.

\subsection{Effect of the cation}

Ionic liquids containing the methyl- $N$-butylpyridinium cation have a more aromatic character than the imidazolium based ionic liquids and this results not only in a high toluene/ heptane selectivity, but also in a high distribution coefficient of toluene. The toluene distribution coefficients at $10(\mathrm{v} / \mathrm{v}) \%$ toluene in the initial mixture of the ionic liquids [mebupy] $\mathrm{BF}_{4}$ and [mebupy] $\mathrm{CH}_{3} \mathrm{SO}_{4}$ at $40{ }^{\circ} \mathrm{C}$ are 0.45 and 0.61 , and the toluene/heptane selectivities 54 and 42, respectively (Fig. 2). Also at $75{ }^{\circ} \mathrm{C}$, both the toluene distribution coefficients $(0.48$ and 0.47 ) and the selectivities (39 and 26) with these two ionic liquids are higher than those with sulfolane (Fig. 3).

The quaternary phosphonium and ammonium ionic liquids show a low toluene/heptane selectivity ( 7 and 9 , respectively) and relatively high distribution coefficients $(0.85$ and 0.93$)$. Also the isoquinolinium ionic liquid shows a low toluene/heptane selectivity of 13 . The experiments with this ionic liquid were carried out at $90^{\circ} \mathrm{C}$, because its melting point was about $88^{\circ} \mathrm{C}$. Although a higher selectivity would be expected, due to the conjugated aromatic core of the isoquinolinium cation [49], the 
toluene distribution coefficient with the isoquinolinium containing IL is 0.30 , slightly lower than that with sulfolane (0.33).

With an aromatic cation, such as pyridinium, both the toluene distribution coefficient and the toluene/heptane selectivity is higher than with other IL's.

\subsection{Effect of the anion}

The nature of the anion has also an important effect. Hanke et al. [21] reported that the solute-solvent interaction of benzene with the chloride ion of the ionic liquid [mmim] $\mathrm{Cl}$ is much stronger than that with the [mmim] cation and that this interaction is dominated by the electrostatic terms. Also a difference in interaction with benzene was found between $[\mathrm{mmim}] \mathrm{Cl}$ and $\left[\mathrm{mmim}^{-} \mathrm{PF}_{6}\right.$.

With $\mathrm{HSO}_{4}^{-}$, the toluene distribution coefficient is very low, around 0.07 at $40{ }^{\circ} \mathrm{C}$ with $10 \%$ toluene, for both $[\mathrm{Hmim}] \mathrm{HSO}_{4}$ and $[\mathrm{emim}] \mathrm{HSO}_{4}$. At $75{ }^{\circ} \mathrm{C}$, the distribution coefficients are 0.041 and 0.123 , respectively. The distribution coefficients of both toluene and heptane with [emim] containing ionic liquids increase in the following order at $40{ }^{\circ} \mathrm{C}$ : $\mathrm{HSO}_{4}^{-}<\mathrm{C}_{2} \mathrm{H}_{5} \mathrm{SO}_{4}^{-}<$ $\mathrm{BF}_{4}^{-}<\mathrm{CH}_{3} \mathrm{SO}_{3}^{-}<\left(\mathrm{C}_{2} \mathrm{H}_{5}\right)_{2} \mathrm{PO}_{4}^{-}$. Since the solubility of heptane increases more in this series than that of toluene, the toluene/ heptane selectivity decreases in this order. At $75{ }^{\circ} \mathrm{C}$, the order in the distribution coefficient with the [emim] containing ionic liquids is: $\mathrm{HSO}_{4}^{-} \approx \mathrm{CH}_{3} \mathrm{SO}_{3}^{-}<\mathrm{C}_{2} \mathrm{H}_{5} \mathrm{SO}_{4}^{-}<\mathrm{BF}_{4}^{-}<\mathrm{C}_{7} \mathrm{H}_{7} \mathrm{SO}_{3}^{-}<$ $\left(\mathrm{C}_{2} \mathrm{H}_{5}\right)_{2} \mathrm{PO}_{4}^{-}$. The toluene/heptane selectivity at $75{ }^{\circ} \mathrm{C}$ decreases in the following order: $\mathrm{HSO}_{4}^{-} \approx \mathrm{CH}_{3} \mathrm{SO}_{3}^{-}>$ $\mathrm{C}_{2} \mathrm{H}_{5} \mathrm{SO}_{4}^{-}>\mathrm{C}_{7} \mathrm{H}_{7} \mathrm{SO}_{3}^{-}>\mathrm{BF}_{4}^{-}>\left(\mathrm{C}_{2} \mathrm{H}_{5}\right)_{2} \mathrm{PO}_{4}^{-}$.

With tetrafluoroborate as anion at $40{ }^{\circ} \mathrm{C}$, both the toluene distribution coefficients $\left(0.30\right.$ for $\left[\mathrm{emim}^{\circ} \mathrm{BF}_{4}, 0.38\right.$ for [bmim] $\mathrm{BF}_{4}$ and 0.45 for [mebupy] $\left.\mathrm{BF}_{4}\right)$ and the toluene/heptane selectivities are high $\left(34,49\right.$ and 54 , respectively). At $75^{\circ} \mathrm{C}$, also relatively high distribution coefficients $(0.25,0.29$ and 0.48$)$ and selectivities are observed (25, 32 and 39 , respectively). The same effect of high selectivities with $\mathrm{BF}_{4}^{-}$-containing compounds is reported for olefin/paraffin separations with silver salts. With $\mathrm{AgBF}_{4}$, much higher separation factors are achieved than with other $\mathrm{Ag}$-salts, such as $\mathrm{ClO}_{4}^{-}, \mathrm{CF}_{3} \mathrm{SO}_{3}^{-}, \mathrm{CF}_{3} \mathrm{CO}_{2}^{-}, \mathrm{NO}_{3}^{-}[30,45]$. Although the toluene distribution coefficient for [omim] $\mathrm{BF}_{4}$ is also high: 0.91 at $40{ }^{\circ} \mathrm{C}$ and 0.69 at $75^{\circ} \mathrm{C}$, the toluene/heptane selectivity is, however, low: 7.1 and 5.7, due to the long alkyl chain on the imidazolium group. The only [emim] containing ionic liquid with both a higher toluene distribution coefficient and a higher toluene/heptane selectivity than with sulfolane is [emim] tosylate, probably caused by the aromatic character of the anion (toluene sulfonate), since all other ionic liquids with $[\mathrm{emim}]^{+}$as cation show lower toluene distribution coefficients than with sulfolane.

ILs with $\mathrm{HSO}_{4}^{-}$anions show a low toluene distribution coefficient and ILs with a $\mathrm{BF}_{4}^{-}$anion usually show a relatively high toluene distribution coefficient.

\subsection{Final selection}

Based on the initial screening results, further tests were carried out with the IL [mmim] methylsulfate because it shows the highest toluene/heptane selectivity of all the ionic liquids tested. The ionic liquid [emim] ethylsulfate was selected in order to compare the results of this ionic liquid with [mmim] methylsulfate. Since the ionic liquid [mebupy] $\mathrm{BF}_{4}$ shows at both temperatures a higher toluene distribution coefficient and a higher toluene/heptane selectivity than sulfolane, this ionic liquid was also selected. With these three ionic liquids, more detailed equilibrium experiments for the full concentration range of $0 \%$ to $100 \%$ toluene in heptane at 40 and $75{ }^{\circ} \mathrm{C}$ were carried out.

4.6. Detailed screening experiments of [mmim] methylsulfate,

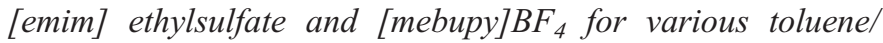
heptane mixtures

From Fig. 4a and b, it can be seen that the distribution coefficient of heptane with [mmim] methylsulfate is very low. Also with [emim] ethylsulfate, the heptane distribution coefficient is low at both temperatures. The heptane distribution coefficient with [mebupy] $\mathrm{BF}_{4}$ is slightly higher. The heptane distribution coefficient with sulfolane increases more with increasing toluene content than with the ionic liquids at both temperatures.

From Fig. 5a and b, it can be seen that the distribution coefficient of toluene, using [emim] ethylsulfate as extractant, remains slightly above 0.2 over the entire concentration range for both 40 and $75{ }^{\circ} \mathrm{C}$. The distribution coefficient of toluene with [mmim] methylsulfate is about 0.08 over the entire concentration range, also for both temperatures. It is lower than with [emim] ethylsulfate, due to the shorter alkyl chain in the imidazolium cation, as expected from the data of Krummen et
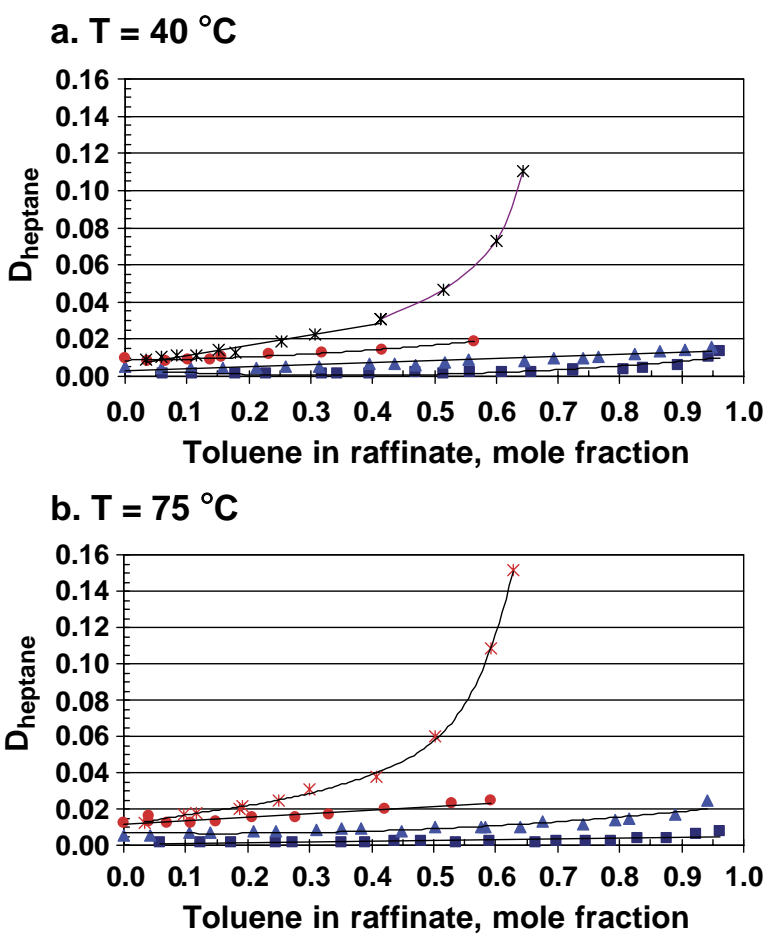

Fig. 4. (a. $T=40{ }^{\circ} \mathrm{C}$, b. $T=75{ }^{\circ} \mathrm{C}$ ) Distribution coefficients for heptane, [mmim]methylsulfate, $\boldsymbol{\Delta}$ [emim]ethylsulfate, $\left[\mathrm{mebupy}_{\mathrm{B}} \mathrm{BF}_{4},{ }^{*}\right.$ sulfolane. 


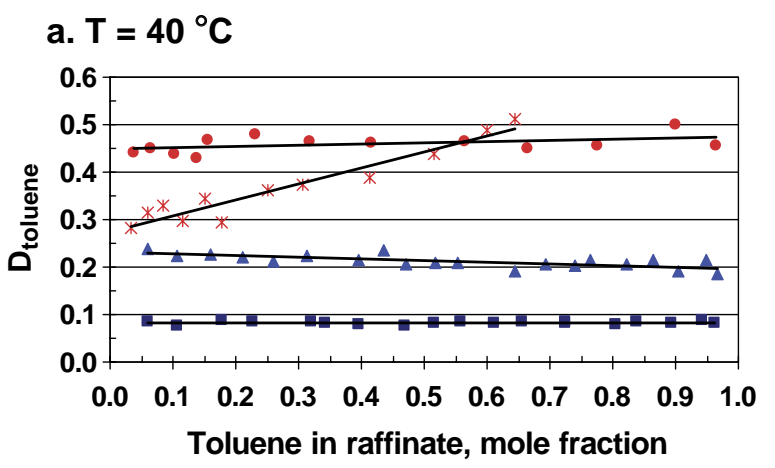

b. $\mathrm{T}=75^{\circ} \mathrm{C}$

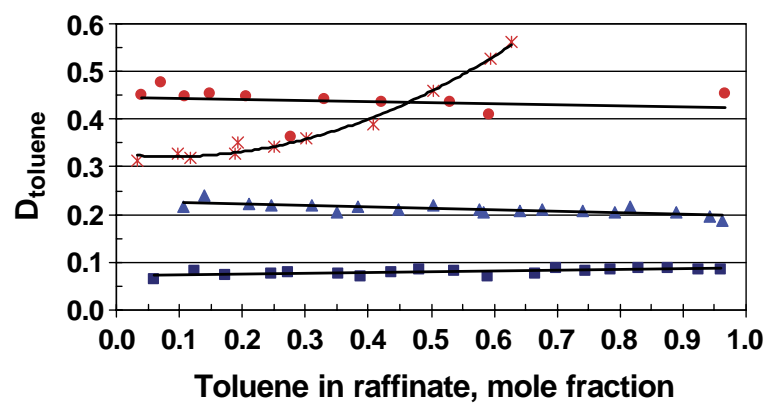

Fig. 5. (a. $T=40{ }^{\circ} \mathrm{C}$, b. $T=75^{\circ} \mathrm{C}$ ) Distribution coefficients for toluene, [mmim]methylsulfate, $\boldsymbol{\Delta}$ [emim] ethylsulfate, $-[$ mebupy $] \mathrm{BF}_{4},{ }^{*}$ sulfolane.

al. [32]. The distribution coefficient of toluene with [mebupy] $\mathrm{BF}_{4}$ is about 0.46 over the entire concentration range at 40 ${ }^{\circ} \mathrm{C}$ and about 0.43 at $75{ }^{\circ} \mathrm{C}$.

The higher distribution coefficient of heptane at a higher temperature is in accordance with the findings of Krummen et al. [32]. From their data, distribution coefficients of heptane with [emim] ethylsulfate can be estimated: 0.0051 at $40{ }^{\circ} \mathrm{C}$ and 0.0069 at $60{ }^{\circ} \mathrm{C}$. With [mmim] methylsulfate, which has both a shorter alkyl chain on the imidazolium ring and a shorter alkyl group in the anion, the selectivity is considerably higher than using [emim] ethylsulfate, which is according to our expectations. The data with $[\mathrm{mmim}]$ methylsulfate are quite scattered, because the analysis of heptane in the extract phase proved to be very difficult as the concentrations were extremely low: between $0.03 \%$ and $0.14 \mathrm{~mol} \%$ at both temperatures. For high toluene concentrations, the selectivity with [mmim] methylsulfate at $75{ }^{\circ} \mathrm{C}$ increases at decreasing toluene content in the feed, but it levels off at concentrations of $65 \mathrm{~mol} \%$ and lower. This is caused by the distribution coefficient of heptane, which increases only slightly from 0.0014 to 0.0018 from $6 \mathrm{~mol} \%$ to $65 \mathrm{~mol} \%$ toluene in the raffinate and increases from 0.0018 to 0.0075 for $65 \mathrm{~mol} \%$ to $96 \mathrm{~mol} \%$ toluene in the raffinate. The distribution coefficients of toluene remained at about the same level of 0.08 over the entire concentration range. With [mebupy] $\mathrm{BF}_{4}$, the toluene/ heptane selectivity increases from 12 to 53 (90 mol\% to 4 mol\% toluene in the raffinate) at $40{ }^{\circ} \mathrm{C}$ and from 17 to 39 (59 to $4 \mathrm{~mol} \%$ toluene in the raffinate) at $75^{\circ} \mathrm{C}$.

The toluene distribution coefficients obtained with [mmim] methylsulfate and [emim] ethylsulfate are lower than with sulfolane. However, with [mebupy] $\mathrm{BF}_{4}$, the toluene distribu- tion coefficient is higher than for sulfolane for concentrations less than $60 \mathrm{~mol} \%$ toluene at $40{ }^{\circ} \mathrm{C}$ and less than $40 \mathrm{~mol} \%$ at $75{ }^{\circ} \mathrm{C}$ (Fig. 5a and b). The toluene/heptane selectivities with these three ILs are a factor of 2-3 higher than those with sulfolane. The toluene/heptane selectivity with sulfolane as extractant increases from $4.6(64 \%$ toluene in the raffinate) to $31\left(3 \mathrm{~mol} \%\right.$ toluene in the raffinate) at $40{ }^{\circ} \mathrm{C}$ and from 3.7 (63 mol\% toluene) to $19(10 \mathrm{~mol} \%$ toluene $)$ at $75{ }^{\circ} \mathrm{C}$, as can be seen in Fig. $6 a$ and $b$.

\subsection{Tests with various aromatic/aliphatic mixtures}

With [mebupy] $\mathrm{BF}_{4}$, which showed of all ionic liquids tested the best combination of a high toluene distribution coefficient and a high toluene/heptane selectivity, further extraction tests with benzene $/ n$-hexane, ethylbenzene $/ n$-octane and $m$-xylene/ $n$-octane mixtures were carried out at 40 and $75{ }^{\circ} \mathrm{C}\left(60{ }^{\circ} \mathrm{C}\right.$ for benzene $/ n$-hexane, because of the low boiling point of hexane, $69^{\circ} \mathrm{C}$ ) with initial aromatic compound concentrations of 5,10 , 15, 30, 45 and $60 \mathrm{v} / \mathrm{v} \%$. The results are shown in Fig. $7 \mathrm{a}$ and $\mathrm{b}$ (distribution coefficients of the alkanes at two temperatures), Fig. 8a and b (distribution coefficients of the aromatics at both temperatures) and Fig. 9a and b (aromatic/aliphatic selectivities at both temperatures).

From Fig. $7 \mathrm{a}$ and $\mathrm{b}$, it is apparent that the distribution coefficients for the aliphatic hydrocarbons decrease with increasing tail length. The distribution coefficients for $n$-octane with either ethylbenzene or $m$-xylene are at the same level. The distribution coefficients for the aliphatic hydrocarbons increase linearly with increasing aromatic concentration in the raffinate

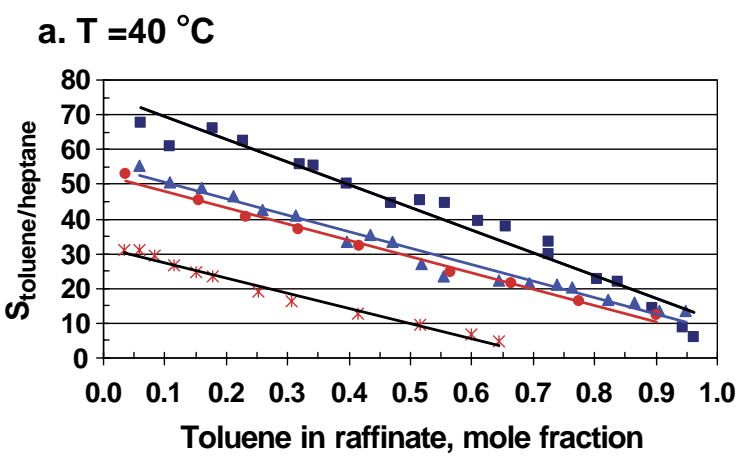

b. $\mathrm{T}=75^{\circ} \mathrm{C}$

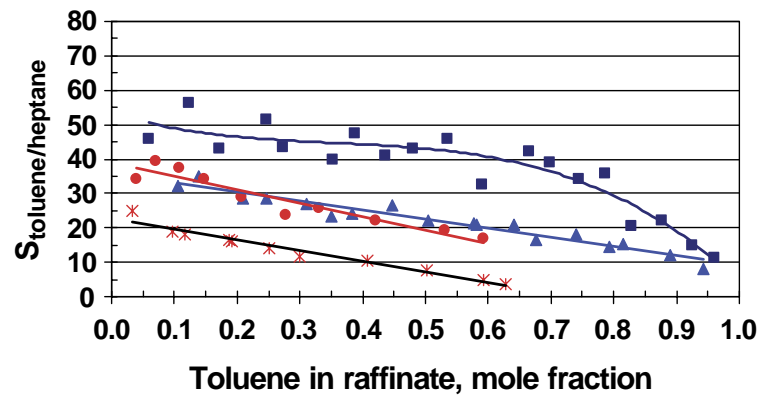

Fig. 6. (a. $T=40{ }^{\circ} \mathrm{C}$, b. $T=75{ }^{\circ} \mathrm{C}$ ) Toluene/heptane selectivities, [mmim]methylsulfate, $\boldsymbol{\Delta}$ [emim] thylsulfate, $\bullet$ mebupy $] \mathrm{BF}_{4},{ }^{*}$ sulfolane. 


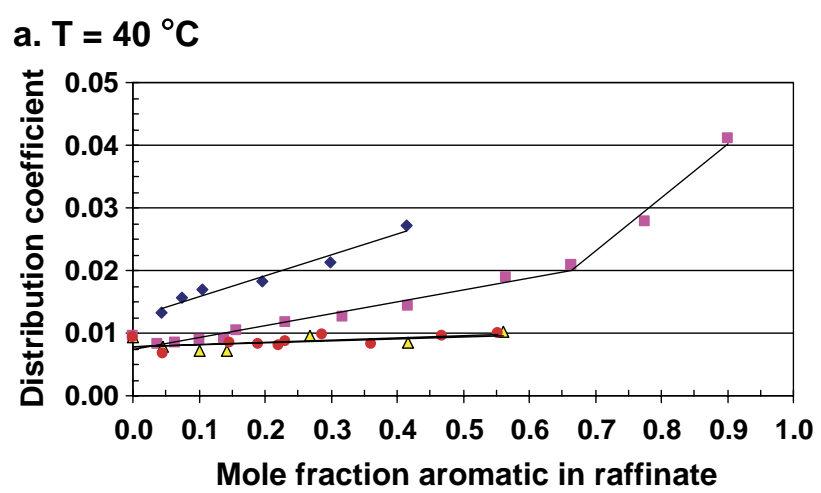

b. $\mathrm{T}=75^{\circ} \mathrm{C}$

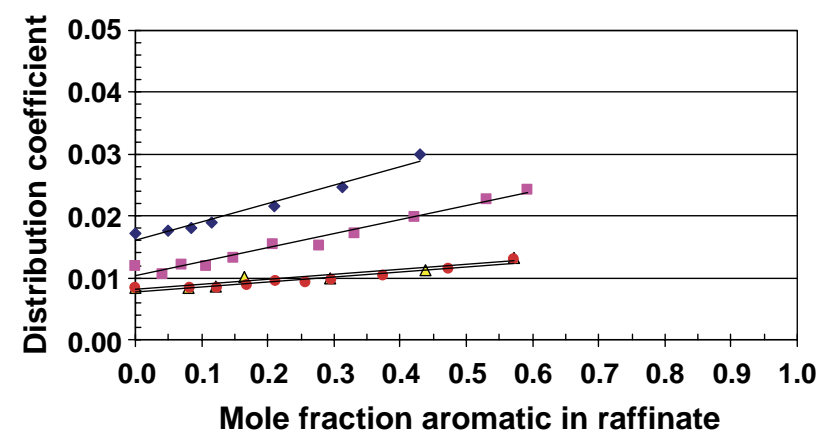

Fig. 7. (a. $T=40{ }^{\circ} \mathrm{C}$, b. $T=75{ }^{\circ} \mathrm{C}$ ) Distribution coefficients for aliphatic

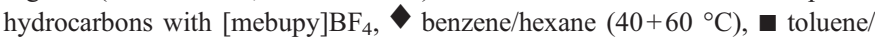
heptane, $\triangle$ ethylbenzene/octane, $m$-xylene/octane.

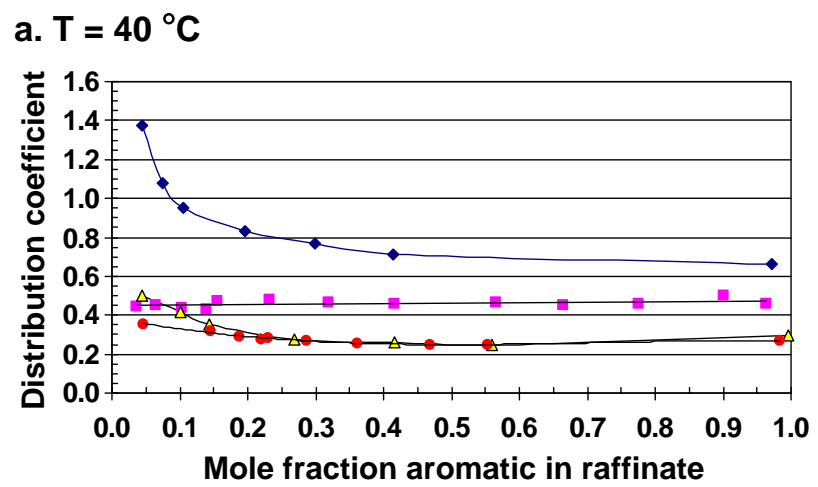

\section{b. $\mathrm{T}=75^{\circ} \mathrm{C}$}

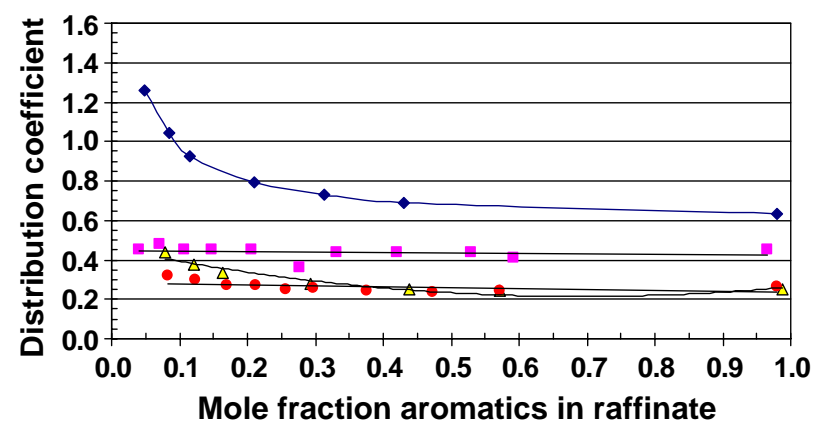

Fig. 8. (a. $T=40{ }^{\circ} \mathrm{C}$, b. $T=75{ }^{\circ} \mathrm{C}$ ) Distribution coefficients for aromatic hydrocarbons with [mebupy] $\mathrm{BF}_{4}, \diamond$ benzene/hexane $\left(40+60{ }^{\circ} \mathrm{C}\right), \boldsymbol{\square}$ toluene/ heptane, $\triangle$ ethylbenzene/octane, $m$-xylene/octane.

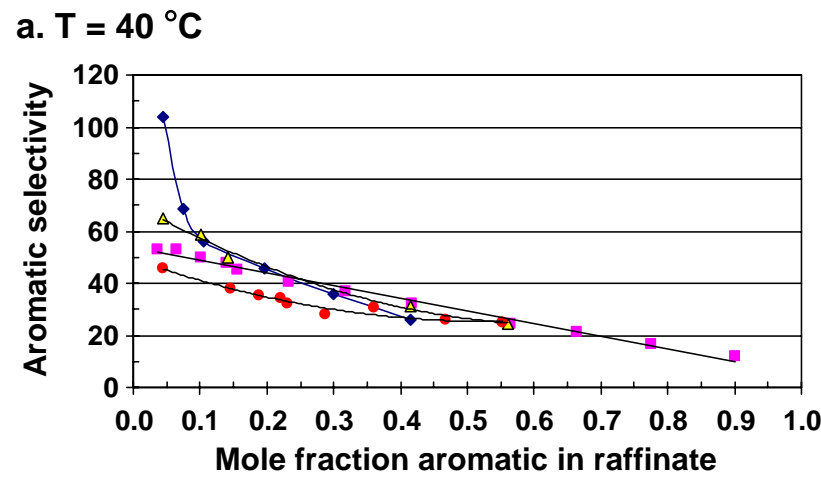

b. $\mathrm{T}=75^{\circ} \mathrm{C}$

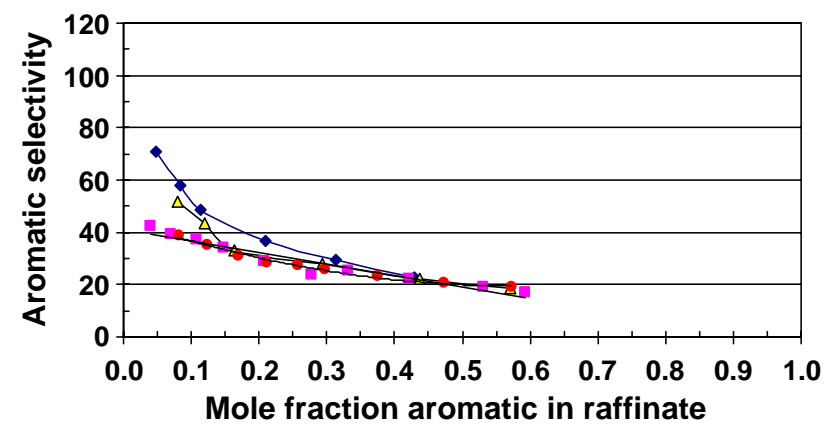

Fig. 9. (a. $T=40{ }^{\circ} \mathrm{C}$, b. $T=75{ }^{\circ} \mathrm{C}$ ) Aromatic/aliphatic selectivities with $\left[\right.$ mebupy] $\mathrm{BF}_{4}, \boldsymbol{b}$ benzene/hexane $\left(40+60{ }^{\circ} \mathrm{C}\right), \boldsymbol{\square}$ toluene/heptane, $\Delta$ ethylbenzene/octane, $m$-xylene/octane.

phase up to a concentration of about $65 \mathrm{~mol} \%$ (Fig. $7 \mathrm{a}, 40^{\circ} \mathrm{C}$ ). Above an aromatic concentration in the raffinate of around $65 \%$, the heptane distribution coefficient increases more than linearly. The same trend can be seen with the heptane distribution coefficient with the ionic liquids [mmim] methylsulfate and [emim] ethylsulfate (Fig. 4a and b). The heptane distribution coefficient with sulfolane increases linearly with increasing toluene concentration in the raffinate up to $40 \mathrm{~mol} \%$. At higher concentrations than $40 \%$, the increase is steeper. At higher temperatures, the distribution coefficients for the aliphatic hydrocarbons are higher.

In Fig. 8a and b, the same general trend can be seen for decreasing distribution coefficients of the aromatic compounds. Also hardly any differences in distribution coefficients can be detected for ethylbenzene and $m$-xylene, at least at aromatic concentrations in the raffinate phase above around $25 \%$. At lower concentrations of the aromatic compound in the raffinate, the distribution coefficients of ethylbenzene and $m$-xylene are increasing and approaching or even surpassing that of toluene.

Since the distribution coefficients for the aliphatic hydrocarbons decrease and those for the aromatic compounds increase at decreasing aromatic concentration in the raffinate, it follows that the aromatic/aliphatic selectivities increase at lower aromatic content in the raffinate. As the distribution coefficients of both the $n$-alkanes and alkyl benzenes decrease with increasing alkyl chain in a similar way, it follows that also the aromatic/aliphatic selectivities are quite similar, except at low aromatic concentrations, as can be seen in Fig. 9a and b. 
The interaction between the ionic liquid [mebupy] $\mathrm{BF}_{4}$ and the alkyl benzenes is most probably of an ionic- $\pi$ nature. Therefore, this interaction is not much affected by the temperature, as can be seen from Fig. 8a and b. This ionic interaction explains also the higher distribution coefficients for benzene, which is the most aromatic compound of the alkyl benzenes tested.

The selectivities with sulfolane for the same combinations of aromatic/aliphatic compounds are also in the same range of each other $\left(S_{\text {benz/hex }}=33, S_{\text {tol/hept }}=29, S_{m \text {-x/oct }}=35\right)[20,27]$, but much lower than those with the ionic liquid.

\subsection{Regeneration of the ionic liquids}

Evaporating the organic compounds from the extract could easily regenerate the ionic liquids as well as the organic compound used in the extraction. Visible inspection of the NMR spectra of both the original ionic liquid and the regenerated product showed no differences between the two samples. This means that no degradation of the ionic liquid after repeated recycling could be detected. This confirms the assumption that the regeneration and recycling of the ionic liquids are indeed simple. Most of the results shown were obtained with regenerated ionic liquids.

The presence of the ionic liquid [mebupy] $\mathrm{BF}_{4}$ in the raffinate phase is very low, in the order of $0.3 \mathrm{~mol} \%$. The average concentration of the ionic liquid [emim] ethylsulfate in the raffinate phase, which also contains some toluene, is low: $0.9 \mathrm{~mol} \%$ at $40{ }^{\circ} \mathrm{C}$ and $2.5 \mathrm{~mol} \%$ at $75{ }^{\circ} \mathrm{C}$. Removal of these ionic liquids from the raffinate phase is possible by using water, since these ionic liquids are water-soluble.

\section{Conclusions}

Ionic liquids are suitable for the separation of aromatic hydrocarbons from mixtures of aromatic and aliphatic hydrocarbons. The ionic liquids $[\mathrm{bmim}] \mathrm{BF}_{4},[$ mebupy $] \mathrm{BF}_{4}$, [mebupy] $\mathrm{CH}_{3} \mathrm{SO}_{4}$, tested at $40{ }^{\circ} \mathrm{C}$, and also [emim $] \mathrm{C}_{7} \mathrm{H}_{7} \mathrm{SO}_{3}$, tested at $75{ }^{\circ} \mathrm{C}$, are the most suitable ones for extraction of toluene from toluene/heptane mixtures. Both the equilibrium distribution coefficients of toluene and the toluene/heptane selectivities are higher with these ionic liquids than with sulfolane. The IL [mebupy] $\mathrm{BF}_{4}$ showed the best combination of both a high toluene distribution coefficient and a high toluene/heptane selectivity.

The distribution coefficients of the aliphatic hydrocarbons decrease with increasing length of the compound and just as the distribution coefficients of the aromatic compounds decrease with an increasing alkyl chain on the benzene ring.

The aromatic/aliphatic selectivities (benzene/hexane, toluene/heptane, ethylbenzene/octane and $m$-xylene/octane) using [mebupy] $\mathrm{BF}_{4}$ increase with decreasing concentration of the aromatic compound in the raffinate phase. The aromatic/ aliphatic selectivities are all in the same range of each other. Therefore, the selection of toluene/heptane as a model for aromatic/aliphatic separations is a valid one.
Calculation of selectivities from activity coefficients at infinite dilution cannot be used as reliable data for an actual extraction, since they can differ up to a factor of 4 from each other. Therefore, more physical properties of ionic liquids must be determined in order to evaluate their suitability for industrial applications.

The toxicity data of ionic liquids are a prerequisite for application of ionic liquids in industrial processes.

\section{Acknowledgments}

We thank Ms. Mireia Gutiérrez Meseguer and Ms. Marianne Klaren for their participation in the research. Furthermore, we are grateful for the financial support of DSM Research and Senter/Novem.

\section{References}

[1] S.H. Ali, H.M.S. Lababidi, S.Q. Merchant, M.A. Fahim, Extraction of aromatics from naphtha reformate using propylene carbonate, Fluid Phase Equilib. 214 (2003) 25-38.

[2] T.A. Al-Sahhaf, E. Kapetanovic, Measurement and prediction of phase equilibria in the extraction of aromatics from naphtha reformate by tetraethylene glycol, Fluid Phase Equilib. 118 (2) (1996) $271-285$.

[3] A. Arce, O. Rodríguez, A. Soto, Experimental determination of liquidliquid equilibrium using ionic liquids: tert-amyl ethyl ether+ethanol+1octyl-3-methylimidazolium chloride system at 298.15 K, J. Chem. Eng. Data 49 (3) (2004) 514-517.

[4] A. Arce, Oscar Rodríguez, Ana Soto, tert-Amyl ethyl ether separation from its mixtures with ethanol using the 1-butyl-3-methylimidazolium trifluoromethanesulfonate ionic liquid: liquid-liquid equilibrium, Ind. Eng. Chem. Res. 43 (26) (2004) 8323-8327.

[5] W. Arlt, M. Seiler, C. Jork, T. Schneider, (BASF), Ionic liquids as selective additives for the separation of close-boiling or azeotropic mixtures, PCT Int. Appl. WO 2002/074718 A2, 26-09-2002 (2002).

[6] L.A. Blanchard, J.F. Brennecke, Recovery of organic products from ionic liquids using supercritical carbon dioxide, Ind. Eng. Chem. Res. 40 (1) (2001) 287-292 (+ 40, 2550).

[7] A. Bösmann, L. Datsevich, A. Jess, A. Lauter, C. Schmitz, P. Wasserscheid, Deep desulfurization of diesel fuel by extraction with ionic liquids, Chem. Commun. (2001) 2494-2495.

[8] L.C. Branco, João G. Crespo, Carlos A.M. Afonso, Highly selective transport of organic compounds by using supported liquid membranes based on ionic liquids, Angew. Chem., Int. Ed. 41 (15) (2002) 2771-2773.

[9] L.C. Branco, João G. Crespo, Carlos A.M. Afonso, Studies on the selective transport of organic compounds by using ionic liquids as novel supported liquid membranes, Chem. Eur. J. 8 (17) (2002) $3865-3871$.

[10] J.F. Brennecke, E.J Maginn, Ionic liquids: innovative fluids for chemical processing, AIChE J. 47 (11) (2001) 2384-2389.

[11] J. Chen, L-P. Duan, J-G. Mi, W-Y. Feio, Z-C. Li, Liquid-liquid equilibria of multi-component systems including $n$-hexane, $n$-octane, benzene, toluene, xylene and sulfolane at $298.15 \mathrm{~K}$ and atmospheric pressure, Fluid Phase Equilib. 173 (2000) 109-119.

[12] J. Chen, Z. Li, L. Duan, Liquid-liquid equilibria of ternary and quaternary systems including cyclohexane, 1-heptane, benzene, toluene, and sulfolane at 298.15 K, J. Chem. Eng. Data 45 (2000) 689-692.

[13] Y.J. Choi, K.W. Cho, B.W. Cho, Y.-K. Yeo, Optimization of the sulfolane extraction plant based on modeling and simulation, Ind. Eng. Chem. Res. 41 (2002) 5504-5509. 
[14] W. David, T.M. Letcher, D. Ramjugernath, J.D. Raal, Activity coefficients of hydrocarbon solutes at infinite dilution in the ionic liquid, 1-methyl-3octyl-imidazolium chloride from gas-liquid chromatography, J. Chem. Thermodyn. 35 (8) (2003) 1335-1341.

[15] U. Domańska, A. Marciniak, Solubility of 1-alkyl-3-methylimidazolium hexafluorophosphate in hydrocarbons, J. Chem. Eng. Data 48 (3) (2003) 451-456.

[16] J. Dupont, C.S. Consorti, J. Spencer, Room temperature molten salts: neoteric "Green" solvents for chemical reactions and processes, J. Braz. Chem. Soc. 11 (4) (2000) 337-344.

[17] A.G. Fadeev, Micheal M. Meagher, Opportunities for ionic liquids in recovery of biofuels, Chem. Commun. (3) (2001) 295-296.

[18] B. Firnhaber, G. Emmerich, F. Ennenbach, U. Ranke, Separation processes for the recovery of pure aromatics, Erdöl Erdgas Kohle 116 (5) (2000) 254-260.

[19] J. Gmehling, M. Krummen, Einsatz ionischer Flüssigkeiten als selektive Lösungsmittel für die Trennung aromatischer Kohlenwasserstoffe von nichtaromatischen Kohlenwasserstoffen durch extraktive Rektifikation und Extraktion, DE $101 \quad 54 \quad 052$ A1, 10-07-2003 (2003).

[20] S.H. Hamid, M.A. Ali, Comparative study of solvents for the extraction of aromatics from naphtha, Energy Sources 18 (1996) 65-84.

[21] C.G. Hanke, A. Johansson, J.B. Harper, R.M. Lynden-Bell, Why are aromatic compounds more soluble than aliphatic hydrocarbons in dimethylimidazolium ionic liquids? A simulation study, Chem. Phys. Lett. 374 (2003) 85-90.

[22] A. Heintz, D.V. Kulikov, S.P. Verevkin, Thermodynamic properties of mixtures containing ionic liquids: 1 . Activity coefficients at infinite dilution of alkanes, alkenes, and alkylbenzenes in 4-methyl- $n$-butylpyridinium tetrafluoroborate using gas-liquid chromatography, J. Chem. Eng. Data 46 (2001) 1526-1529.

[23] A. Heintz, D.V. Kulikov, S.P. Verevkin, Thermodynamic properties of mixtures containing ionic liquids: 2. Activity coefficients at infinite dilution of hydrocarbons and polar solutes in 1-methyl-3-ethyl-imidazolium bis(trifluoromethyl-sulfonyl) amide and in 1,2-dimethyl-3-ethylimidazolium bis(trifluoromethyl-sulfonyl) amide using gas-liquid chromatography, J. Chem. Eng. Data 47 (2002) 894-899.

[24] A. Heintz, Jochen K. Lehmann, Christiane Wertz, Thermodynamic properties of mixtures containing ionic liquids: 3 . Liquid-liquid equilibria of binary mixtures of 1-ethyl-3-methylimidazolium bis(trifluoromethylsulfonyl)imide with propan-1-ol, butan-1-ol, and pentan-1-ol, J. Chem. Eng. Data 48 (3) (2003) 472-474.

[25] J.D. Holbrey, W.M. Reichert, R.P. Swatloski, G.A. Broker, W.R. Pitner, K.R. Seddon, R.D. Rogers, Efficient, halide free synthesis of new, low cost ionic liquids: 1,3-dialkylimidazolium salts containing methyl- and ethylsulfate anions, Green Chem. 4 (2002) 407-413.

[26] J.D. Holbrey, W.M. Reichert, M. Nieuwenhuyzen, O. Sheppard, C. Hardacre, R.D. Rogers, Liquid clathrate formation in ionic liquidaromatic mixtures, Chem. Commun. 4 (2003) 476-477.

[27] T. Hombourger, L. Gouzien, P. Mikitenko, P. Bonfils, Solvent extraction in the oil industry, in: J.P. Wauquier (Ed.), Petroleum Refining: 2. Separation Processes, Editions Technip, Paris, 2000, pp. 359-456, Ch. 7.

[28] J.G. Huddleston, H.D. Willauer, R.P. Swatloski, A.E. Visser, R.D. Rogers, Room temperature ionic liquids as novel media for 'clean' liquid-liquid extraction, Chem. Commun. 16 (1998) 1765-1766.

[29] R. Kato, J. Gmehling, Activity coefficients at infinite dilution of various solutes in the ionic liquids $[\mathrm{MMIM}]^{+}\left[\mathrm{CH}_{3} \mathrm{SO}_{4}\right]^{-},[\mathrm{MMIM}]^{+}\left[\mathrm{CH}_{3} \mathrm{OC}_{2}\right.$ $\left.\mathrm{H}_{4} \mathrm{SO}_{4}\right]^{-},[\mathrm{MMIM}]^{+}\left[\left(\mathrm{CH}_{3}\right)_{2} \mathrm{PO}_{4}\right]^{-}, \quad\left[\mathrm{C}_{2} \mathrm{H}_{5} \mathrm{NC}_{2} \mathrm{H}_{5}\right]^{+}\left[\left(\mathrm{CF}_{3} \mathrm{SO}_{2}\right)_{2} \mathrm{~N}\right]^{-}$and $\left[\mathrm{C}_{2} \mathrm{H}_{5} \mathrm{NH}\right]^{+}\left[\mathrm{C}_{2} \mathrm{H}_{5} \mathrm{OC}_{2} \mathrm{H}_{4} \mathrm{OSO}_{3}\right]^{-}$, Fluid Phase Equilib. 226 (2004) 37-44.

[30] J.H. Kim, J. Won, Y.S. Kang, Silver polymer electrolytes by $\pi$-complexation of silver ions with polymer containing $\mathrm{C}=\mathrm{C}$ bond and their application to facilitated olefin transport membranes, J. Membr. Sci. 237 (2004) 199-202.

[31] R. Krishna, A.N. Goswami, S.M. Nanoti, B.S. Rawat, M.K. Khana, J. Dobhal, Extraction of aromatics from $63-69{ }^{\circ} \mathrm{C}$ naphtha fraction for food grade hexane production using sulpholane and NMP as solvents, Ind. J. Technol. 25 (1987) 602-606.
[32] M. Krummen, P. Wasserscheid, J. Gmehling, Measurement of activity coefficients at infinite dilution in ionic liquids using the dilutor technique, J. Chem. Eng. Data 47 (2002) 1411-1417.

[33] T.M. Letcher, B. Soko, D. Ramjugernath, N. Deenadayalu, A. Nevines, P.K. Naicker, Activity coefficients at infinite dilution of organic solutes in 1-hexyl-3-methylimidazolium hexafluorophosphate from gas-liquid chromatography, J. Chem. Eng. Data 48 (2003) 708-711.

[34] T.M. Letcher, N. Deenadayalu, Ternary liquid-liquid equilibria for mixtures of 1-methyl-3-octyl-imidazolium chloride + benzene + an alkane at $T=298.2 \mathrm{~K}$ and $1 \mathrm{~atm}, \mathrm{~J}$. Chem. Thermodyn. 35 (1) (2003) 67-76.

[35] T.M. Letcher, N. Deenadayalu, B. Soko, D. Ramjugernath, P.K. Naicker, Ternary liquid-liquid equilibria for mixtures of 1-methyl-3-octylimidazolium chloride + an alkanol+an alkane at $298.2 \mathrm{~K}$ and 1 bar, J. Chem. Eng. Data 48 (4) (2003) 904-907.

[36] T.M. Letcher, P. Reddy, Ternary liquid-liquid equilibria for mixtures of 1hexyl-3-methylimidozolium (tetrafluoroborate or hexafluorophosphate) + ethanol+an alkene at $T=298.2 \mathrm{~K}$, Fluid Phase Equilib. 219 (2) (2004) $107-112$

[37] T.M. Letcher, P. Reddy, Ternary (liquid+liquid) equilibria for mixtures of 1-hexyl-3-methylimidazolium (tetrafluoroborate or hexafluoroborate) + benzene + an alkane at $T=298.2 \mathrm{~K}$ and $p=0.1 \mathrm{MPa}$, J. Chem. Thermodyn. 37 (2005) 415-421.

[38] J.-F. Liu, Y.-G. Chi, G.-B. Jiang, Screening the extractability of some typical environmental pollutants by ionic liquids in liquid-phase microextraction, J. Sep. Sci. 28 (1) (2005) 87-91.

[39] M. Matsumoto, Y. Inomoto, K. Kondo, Selective separation of aromatic hydrocarbons through supported liquid membranes based on ionic liquids, J. Membr. Sci. 246 (1) (2005) 77-81.

[40] Fabrice Mutelet, Vincent Butet, Jean-Noël Jaubert, Application of inverse gas chromatography and regular solution theory for characterization of ionic liquids, Ind. Eng. Chem. Res. 44 (11) (2005) 4120-4127.

[41] B.S. Rawat, I.B. Gulati, Liquid-liquid equilibrium studies for separation of aromatics, J. Appl. Chem. Biotechnol. 26 (1976) 425-435.

[42] D.F. Schneider, Avoid sulfolane regeneration problems, Chem. Eng. Prog. 100 (7) (2004) 29-34.

[43] M.S. Selvan, M.D. McKinley, R.H. Dubois, J.L. Atwood, Liquid-liquid equilibria for toluene+heptane+1-ethyl-3-methylimidazolium triiodide and toluene+heptane+1-butyl-3-methylimidazolium triiodide, J. Chem. Eng. Data 45 (2000) 841-845.

[44] L.-J. Shyu, Z. Zhang, Q. Zhang, (Akzo Nobel), Process for the extraction of an aromatic compound from an aliphatic phase using a non-neutral ionic liquid, PCT Int. Appl. WO 2001/40150 A1, 07-062001 (2001).

[45] S. Sunderrajan, B.D. Freeman, C.K. Hall, I. Pinnau, Propane and propylene sorption in solid polymer electrolytes based on poly(ethylene oxide) and silver salts, J. Membr. Sci. 182 (2001) 1-12.

[46] R.P. Swatloski, J.D. Holbrey, R.D. Rogers, Ionic liquids are not always green: hydrolysis of 1-butyl-3-methylimidazolium hexafluoroborate, Green Chem. 5 (4) (2003) 361-363.

[47] A.E. Visser, R.P. Swatloski, S.T. Griffin, D.H. Hartman, R.D. Rogers, Liquid/liquid extraction of metal ions in room temperature ionic liquids, Sep. Sci. Technol. 36 (5\&6) (2001) 785-804.

[48] A.E. Visser, Richard P. Swatloski, W. Matthew Reichert, Rebecca Mayton, Sean Sheff, Andrzej Wierzbicki, James H. Davis Jr., Robin D. Rogers, Task-specific ionic liquids for the extraction of metal ions from aqueous solutions, Chem. Commun. (1) (2001) 135-136.

[49] A.E. Visser, J.D. Holbrey, R.D. Rogers, Hydrophobic ionic liquids incorporating $N$-alkylisoquinolinium cations and their utilization in liquid-liquid separations, Chem. Commun. 23 (2001) 2484-2485.

[50] A.E. Visser, Metal ion separations in aqueous biphasic systems and room temperature ionic liquids. $\mathrm{PhD}$ thesis, University of Alabama, Tuscaloosa, AL, USA, 2002.

[51] W. Wang, Z.M. Gou, S.L. Zhu, Liquid-liquid equilibria for aromatics extraction systems with tetraethylene glycol, J. Chem. Eng. Data 43 (1) (1998) 81-83.

[52] G.-T. Wei, Z. Yang, C.-J. Chen, Room temperature ionic liquid as a novel medium for liquid/liquid extraction of metal ions, Anal. Chim. Acta 488 (2) (2003) $183-192$. 
[53] K. Weissermel, H.-J. Arpe, Industrial Organic Chemistry, 4th Completely Revised edition, Wiley-VCH, Weinheim, 2003, pp. 313-336.

[54] J. Willems, J. Nys, The preparation of some quaternary ammonium salts, Bull. Soc. Chim. Belg. 66 (1957) 502-511.

[55] C.-T. Wu, Kenneth N. Marsh, Alexander V. Deev, John A. Boxal, Liquidliquid equilibria of room-temperature ionic liquids and butan-1-ol, J. Chem. Eng. Data 48 (3) (2003) 486-491.

[56] Y. Yorulmaz, F. Karpuzcu, Sulpholane versus diethylene glycol in recovery of aromatics, Chem. Eng. Res. Des. 63 (1985) 184-190.
[57] S.G. Zhang, Z. Conrad Zhang, Novel properties of ionic liquids in selective sulfur removal from fuels at room temperature, Green Chem. 4 (4) (2002) $376-379$.

[58] S.G. Zhang, Qinglin Zhang, Z. Conrad Zhang, Extractive desulfurization and denitrogenation of fuels using ionic liquids, Ind. Eng. Chem. Res. 43 (2) (2004) 614-622.

[59] J. Eßer, P. Wasserscheid, A. Jess, Deep desulfurization of oil refinery systems by extraction with ionic liquids, Green Chem. 6 (7) (2004) $316-322$. 